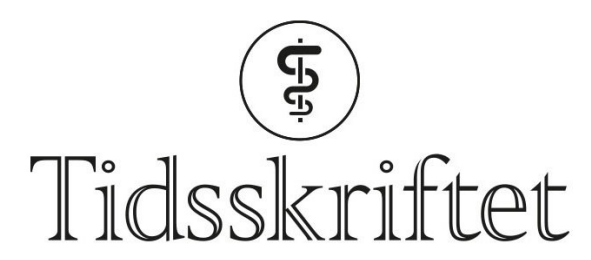

DEN NORSKE LEGEFORENING

\title{
Hvilken troponinanalyse er best?
}

FRA ANDRE TIDSSKRIFTER

KARI TVEITO

Tidsskriftet

Troponin T og troponin I er like gode markører for skade på koronarkar, mens pro-BNP er best egnet til å si noe om langtidsprognosen etter akutt koronarsyndrom. Dette viser en ny norsk studie.

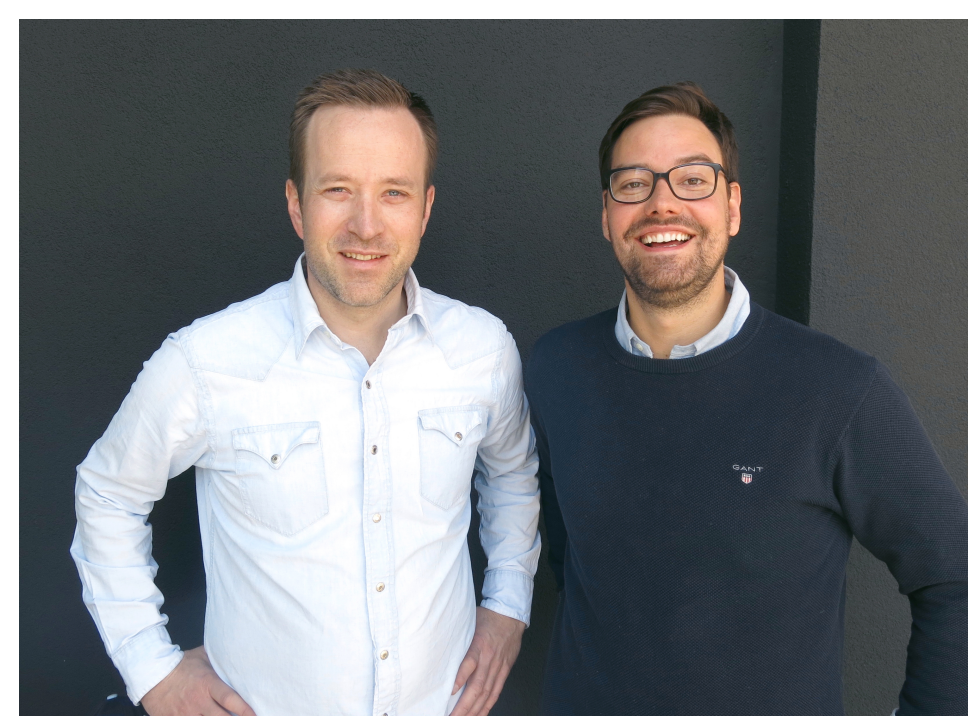

Jørgen Gravning (til venstre) og Brede Kvisvik. Foto: Kristian Sydnes

Ved akutt koronarsyndrom er det viktig å stille riktig diagnose tidlig. Troponin T og troponin I er to biomarkører som raskt $ø$ ker i mengde i blodbanen ved hjerteskade. Ved såkalte høysensitive troponinmetoder kan man presist påvise små økninger i troponinnivå. Slike analyser er derfor velegnet for tidlig diagnostikk. 


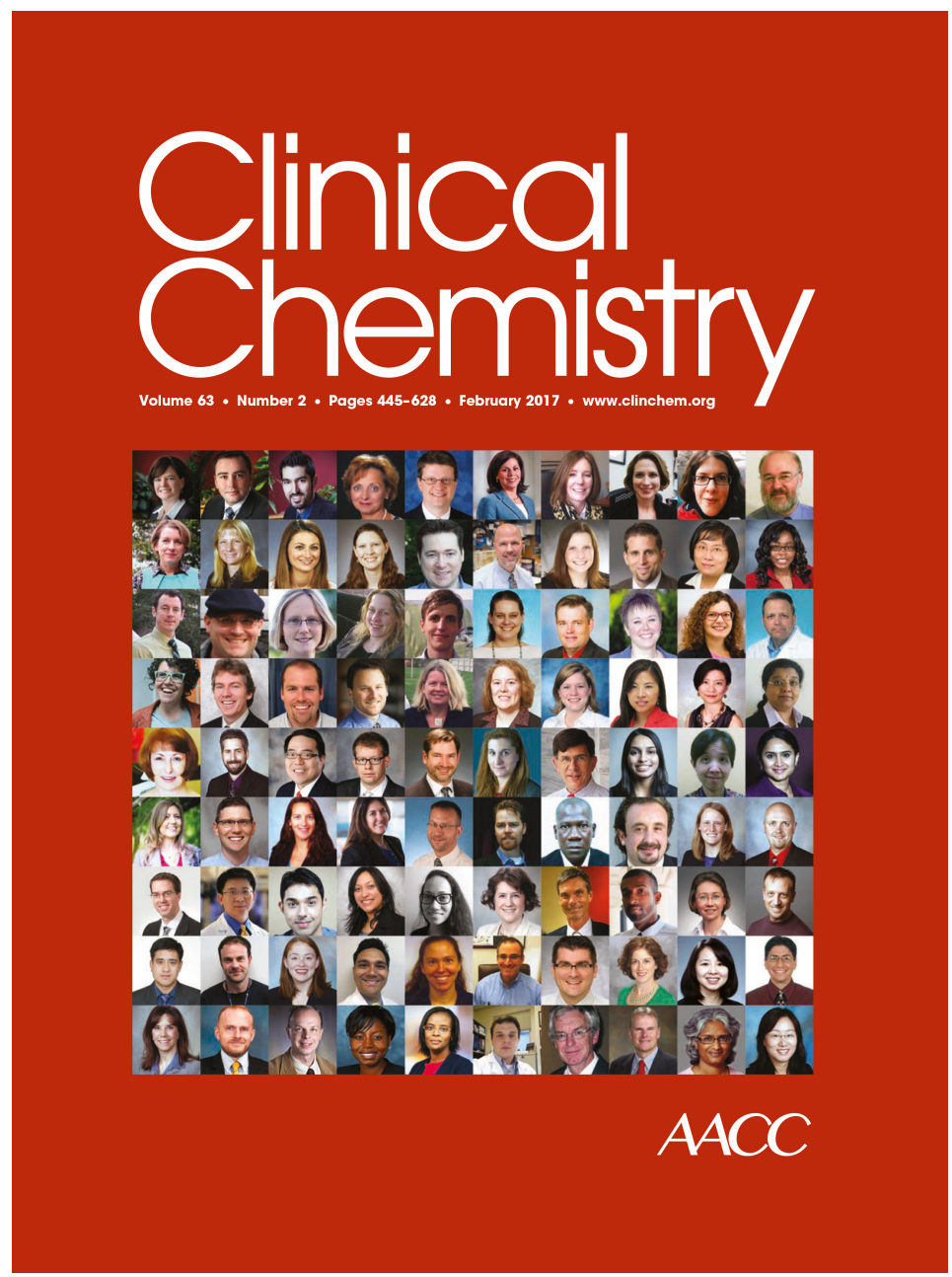

Artikkelen ble publisert i Clinical Chemistry i februar 2017

Den prediktive verdien av hjertemarkører for koronarskade og prognose hos pasienter med akutt koronarsyndrom er nylig studert i en norsk studie publisert i tidsskriftet Clinical Chemistry (1). Serumkonsentrasjoner av troponin T, troponin I og pro-B-type natriuretisk peptid (pro-BNP) ble målt hos 390 pasienter med akutt koronarsyndrom uten ST-elevasjon på EKG. Pasientene ble i gjennomsnitt fulgt opp i overkant av åtte år.

Troponin I-nivåene $\varnothing$ kte signifikant mer enn troponin T-nivåene, men det var ingen forskjell i egnethet til å forutsi skade på koronarkar ved angiografi. Nivået av pro-BNP hadde større prediktiv verdi for langtidsprognosen enn nivået av troponin T og troponin I.

- Hensikten med denne studien var å se etter forskjeller mellom troponintestene som kan ha betydning i den kliniske hverdagen, sier Jørgen Gravning, som er studiens sisteforfatter. Dette er en viktig problemstilling, fordi sykehusene i Norge benytter ulike analysemetoder for å måle troponin, sier han.

- Vi konkluderte med at nivåene av troponin T og troponin I er like gode til å predikere signifikante koronare stenoser, men at variasjonen mellom dem var stor. Dette skyldes mest sannsynlig biologiske forskjeller mellom de ulike troponinene. Et annet viktig funn var at pro-BNP var klart best som prediktiv markør for mortalitet, sier Gravning.

\section{Forskningsgruppen}

Studien er et samarbeidsprosjekt mellom Center for Cardiological Innovation, Oslo universitetssykehus, Rikshospitalet, og Cardiothoracic Research Group ved Akershus universitetssykehus. Førsteforfatter Brede Kvisvik er stipendiat ved Akershus universitetssykehus. Jørgen Gravning ledet arbeidet i samarbeid med Helge Røsjø ved Cardiothoracic Research Group og professor Thor Edvardsen ved Center for Cardiological Innovation. 
LITTERATUR:

1. Kvisvik B, Mørkrid L, Røsjø H et al. High-sensitivity troponin T vs I in acute coronary syndrome: Prediction of significant coronary lesions and long-term prognosis. Clin Chem 2017; 63: 552 - 62.

Publisert: 26. juni 2017. Tidsskr Nor Legeforen. DOI: 10.4045/tidsskr.17.0432

(C) Tidsskrift for Den norske legeforening 2020. Lastet ned fra tidsskriftet.no 